\title{
DISTRIBUTION RANGE EXTENSION AND FIRST RECORD OF TONKIN NUMBFISH NARCINE PRODORSALIS (BESSEDNOV, 1966) (TORPEDINIFORMES: NARCINIDAE) AN ELECTRIC RAY IN BANGLADESH WATERS
}

\author{
Alifa Bintha Haque* and Nazia Hossain \\ Department of Zoology, University of Dhaka, Dhaka-1000, Bangladesh
}

\begin{abstract}
Three Tonkin numbfish, Narcine prodorsalis were caught off the coast of Bangladesh in April 2018. Amongst these three specimens, one was morphometrically measured, photographed and transported to be persevered and catalogued at the zoological museum in the University of Dhaka. The specimens were morphologically identified using taxonomic keys and DNA samples (fin clips) have been collected for further studies. These specimens represent the first record of Narcine prodorsalis in Bangladesh waters and extend its distribution range. This is the first western most confirmed record of this species from its previously designated range in the western Pacific and Eastern Indian ocean. This contemporary record includes Bay of Bengal within its current distribution range.
\end{abstract}

Key words: Bay of Bengal, Elasmobranchs, Electric rays, Marine conservation

\section{INTRODUCTION}

A diverse group of fish, the electric rays are circumglobally distributed in warm, sub-temperate marine waters to tropical continental and continental insular waters (Carvalho 1999a, de Carvalho et al. 2002). They inhabit in a range of habitats including sandy beaches, muddy bays, estuaries, coral reefs, river mouth with an exception to rivers (Carvalho 1999a). Although very easily identifiable morphologically from other batoids (de Carvalho et al. 2002) they are taxonomically extremely neglected (de Carvalho 2003). So far, 55 species of electric rays under 10 genera have been recognized globally (Bigelow and Schroeder 1953, de Carvalho 1999b) and the family Narcinidae has 9 genera and 24 species (Estupiñan-Montaño and Galván-Magaña 2015) alone.

Narcine prodorsalis so far has been native to China, Indonesia, Singapore, Taiwan, Province of China, Thailand and Viet Nam (Wang et al. 2009) but also have been reported from Thailand and Myanmar (Monkolprasit 1941, Howard et al. 2015) which asserts that, no confirmed record of $N$. prodorsalis has been reported western to Andaman sea, specifically in the Bay of Bengal region or western to that in the Arabian sea or adjacent waters so far. Which also is confirmed by the distribution range map generated by IUCN (Fig. 1). However, South-east Asian continental shelf has been incorporated to be a very likely range of the species (Last et al. 2016).

*Author for correspondence: <alifa.haque@du.ac.bd>

(C) 2018 Zoological Society of Bangladesh DOI: http://dx.doi.org/10.3329/bjz.v46i2.39048 
Prior to this current report of $N$. prodorsalis, only two species of Narcinid electric rays were recorded off the coasts of Bangladesh (e.g. N. temlei and $N$. brunnea) along with a numbray Narke dipterygia (Hoq et al. 2011, Rahman et al. 2009). Although, six species from the family of Narcinidae have been reported from Indian waters (e.g. Benthobatis moresbyi, Narcine brunnea, Narcine lingual, Narcine timlei, Narcine cf oculifera, Narcine maculata) with an unconfirmed record of $N$. prodorsalis (Akhilesh et al. 2014); and from Arabian sea and the surrounding gulfs, five species of Narcine (e.g., Narcine lingula, Narcine timlei, Narcine oculifera, Narcine atzi and Narcine rierai) have been documented (de Carvalho et al. 2003). Hence, no conformed record of $N$. prodorsalis was documented further west to the Andaman sea.

$N$. prodorsalis is found at $40-100 \mathrm{~m}$ within both inshore and offshore in continental waters (de Carvalho et al. 1999b) and presumably demersal trawl fishing is a big threat as they may take them as by-catch (Wang et al. 2009). The species is not very common to site and due to less reports and species-specific studies not much information on biology, full distribution range and threats are available. Hence, $N$. prodorsalis has been designated as data deficient the International Union of Conservation of Nature (IUCN) in 2009 (Wang et al. 2009).

The aim of this paper was to report the 1 st record of a female $N$. prodorsalis in Bay of Bengal, off the coasts of Bangladesh and extending the range of the geographical distribution of the species further west to Andaman sea, within the Bay of Bengal.

\section{MATERIAL AND METHODS}

A Tonkin numbfish N. prodorsalis (Bessednov, 1966) has been reported from Bangladesh on 15 April, 2018 while a regular field visit was conducted for identifying the trade chain of shark and ray products in Bangladesh. The specimen was recorded from the Bangladesh Fisheries Development Corporation (BFDC) landing site of Cox's Bazar (Fig. 1). The specimen was encountered in a pile of different smaller sharks and rays (Gymnura sp., Himantura sp., Chiloscyllium sp., Glaucostegus sp.) landed on the same day either targeted by un-baited hooks or as a by-catch in a purse-bag net to targeting an array of marine fish by artisanal fishers in the area. The specimen was identified following Last et al. 2016. The specimen was collected and transported as a voucher specimen at the Dr. Kazi Zakir Hossain Museum, Department of Zoology, University of Dhaka (the catalogue number is yet to be given) and preserved in 30\% formalin. Prior to preservation tissue samples were collected and preserved in $98 \%$ ethanol for further molecular studies. A tape measure and Vernier caliper was used to measure point to point to the nearest millimeter of 
44 different morphometric measurements following de Carvalho (1999b). All measurements are presented in Table 1 and are shown in proportion with the total length (TL).

A rapid informal survey in the landing site has been conducted post encountering the species amongst the regular landing site workers and fishers available that day $(n=15)$. The landing site workers, fishers and fish traders were asked questions about the availability of the species in this area, how many times in their lifetime working in the landing site, they have encountered it and when was the last time they have seen it. They were shown the photograph prior to asking the following questions.

1. Have you ever seen this species (upon showing the photograph)?

2. How often the species is landed here?

3. When was the last time you have encountered this species?

4. What are the gears they are entangled in or caught by?

5. Is it an important species for you (economic value)?

\section{RESULTS AND DISCUSSION}

This study reports the presence of the Tonkin numbfish Narcine prodorsalis (Bessednov 1966) (Batoidae: Torpediniformes: Narcinidae) in Bangladesh waters in the Bay of Bengal region for the first time. To date, this is the western most confirmed record of this species in the Western Indo Pacific, from its previous range in the western Pacific and Eastern Indian ocean (Fig. 1). Thus, confirming and increasing its range till the Bay of Bengal, Bangladesh region. The distribution range of Narcine prodorsalis has extended approximately another ca. $700 \mathrm{~km}$ from Andaman sea with this report. Including this, three electric ray species have been recorded in Bangladesh till date, indicating under representation of this group in the Bay of Bengal indicating Wallacean and Prestonian knowledge shortfall. With this record of a female Tonkin numbfish $(\mathrm{TL}=46.6 \mathrm{~cm})$ in the Bay of Bengal, Bangladesh region (Fig. 2), the species richness of elasmobranchs increased. This study extends the geographical distribution of $N$. prodorsalis in the Bay of Bengal (Fig. 1).

The $N$. prodorsalis specimen along with its measurements is listed in Table 1 . The specimen was recorded in the Bangladesh Fisheries Development Corporation's landing site within a pile of other ray species in Cox's Bazar. The identification was unmistakable due to its very distinct morphological features. The $N$. prodorsalis is medium size animals characterized by having numerous small regular dark black and brown spots and the background is light brown and an oval to heart shaped disc (Last et al. 2016). The species may resemble with Chinese numbfish and Smallspot numbfish but relatively distinguishable by the color pattern and smaller spots (Last et al. 2016). Last et al. 2016 
assumed its widespread distribution on the continental shelf of South-east Asia and this report confirms that.

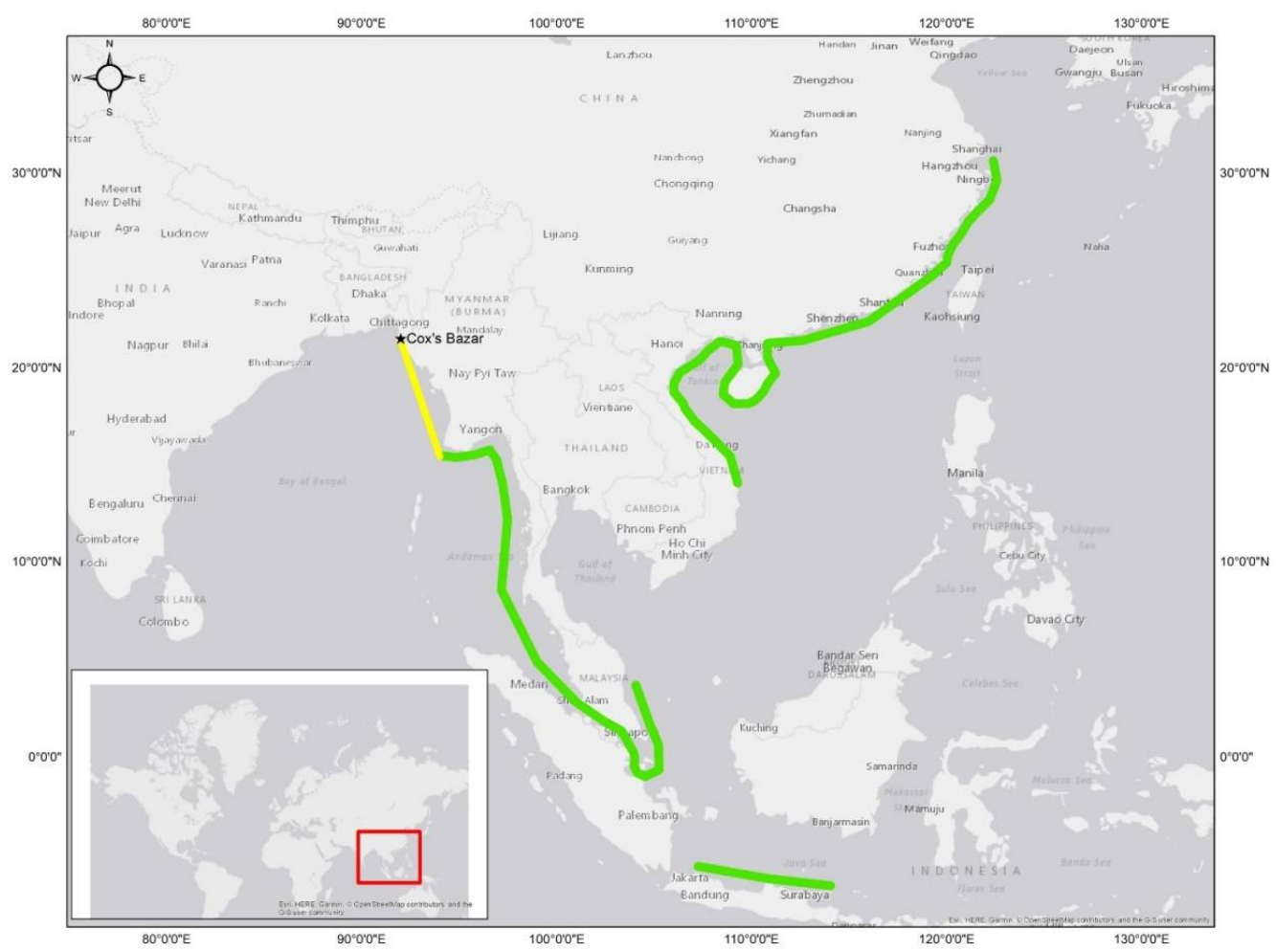

Fig. 1. Area of occurrence of Tonkin numbfish (inset) and map showing previously designated distribution range (extant) in green line according to IUCN distribution range map (http://maps.iucnredlist.org/map.html?id=161545). The extension in distribution range is shown in yellow from Andaman sea to Cox's Bazar. Black star: site (Cox's Bazar) from where the specimens were reported.

Upon discovering the specimen, a very rapid informal survey was conducted amongst the regular landing site workers to understand the frequency of the species landing in Cox's Bazar. Amongst all the respondents $33 \%(n=5)$ have seen the specimen before and $\sim 66 \%(n=10)$ have never seen the species before. The respondents who have encountered the species stated that this is an extremely rare species to be landed and they normally encounter one in years (25 years) apart. This is normally caught by the long line hooks or as a non- discarded 


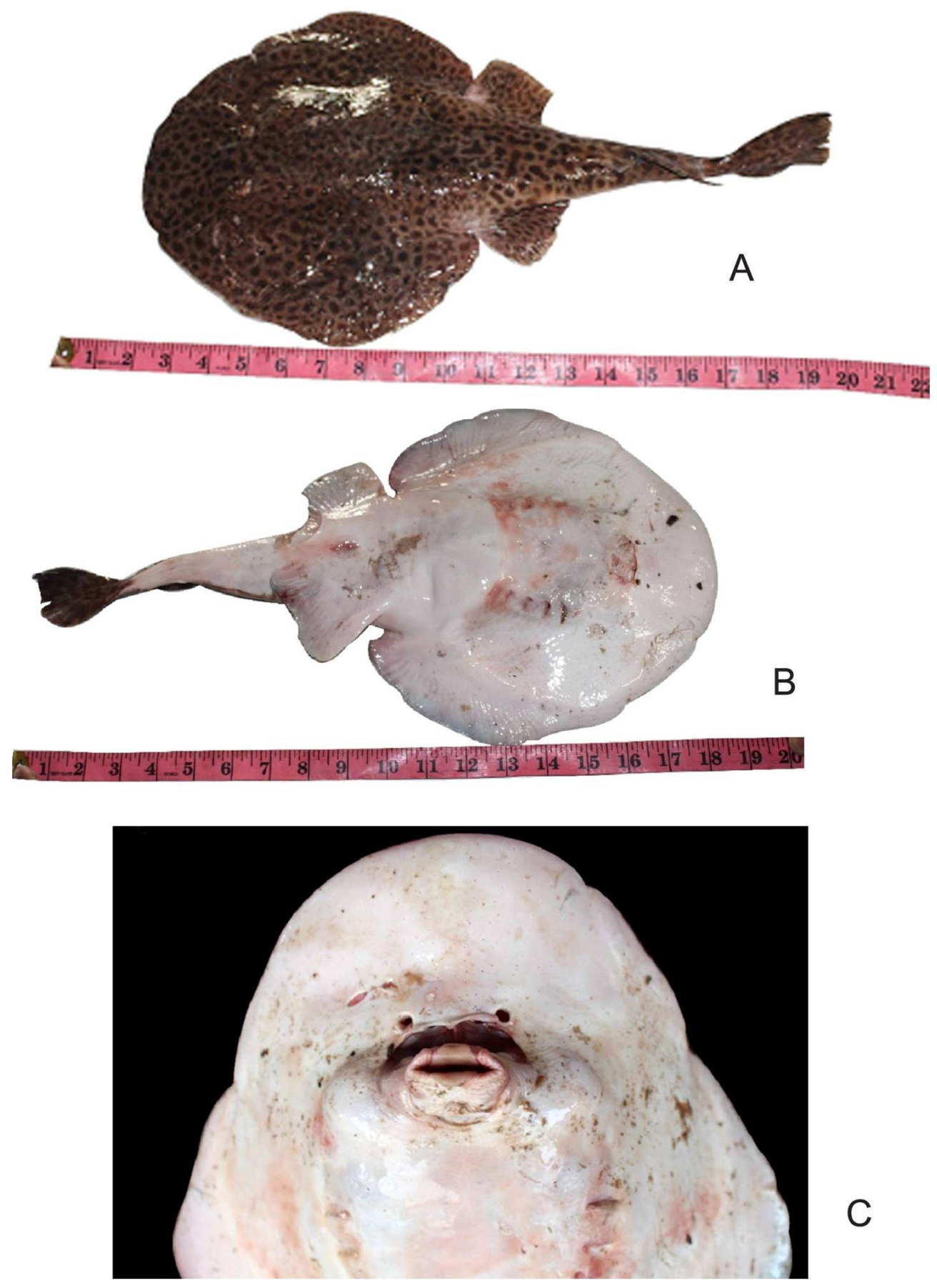

Fig. 2: A and B. Dorsal and ventral view of the specimen Narcine prodorsalis, total length $46.6 \mathrm{~cm}$; Tape measure is set. C. Protrusible mouth structure of the specimen recorded. 
Table 1. Morphometric measurements of the reported specimen of Narcine prodorsalis recorded from Cox's Bazar, Bangladesh following de Carvalho (1999b)

\begin{tabular}{|c|c|c|c|c|c|c|c|}
\hline $\begin{array}{l}\text { Sl. } \\
\text { No. }\end{array}$ & & $\begin{array}{l}\text { Measure- } \\
\text { ments } \\
(\mathrm{cm})\end{array}$ & $\begin{array}{l}\% \text { of } \\
\mathrm{TL}\end{array}$ & $\begin{array}{l}\text { Sl. } \\
\text { No. }\end{array}$ & & $\begin{array}{l}\text { Measure- } \\
\text { ments } \\
(\mathrm{cm})\end{array}$ & $\begin{array}{c}\text { \% of } \\
\text { TL }\end{array}$ \\
\hline 1 & Sex & Female & & & & & \\
\hline 2 & Total length (TL) & 46.6 & & 24 & $\begin{array}{l}\text { Distance between } \\
\text { nostrils (DBN) }\end{array}$ & 2.4 & 5.15 \\
\hline 3 & Disc width (DW) & 26.0 & 55.79 & 25 & $\begin{array}{l}\text { Distance between } 1^{\text {st }} \\
\text { gill openings (FGO) }\end{array}$ & 1.2 & 2.58 \\
\hline 4 & Disc length (DL) & 22.5 & 48.28 & 26 & $\begin{array}{l}\text { Distance between last } \\
\text { gill openings (LGO) }\end{array}$ & 0.8 & 1.72 \\
\hline 5 & $\begin{array}{l}\text { Pre-orbital snout } \\
\text { length (PBS) }\end{array}$ & 6.7 & 14.38 & 27 & Pelvic fin length (PFL) & 6.8 & 14.59 \\
\hline 6 & $\begin{array}{l}\text { Pre-oral snout length } \\
\text { (POS) }\end{array}$ & 6.6 & 14.16 & 28 & Pelvic fin width (PFW) & 5.0 & 10.73 \\
\hline 7 & $\begin{array}{l}\text { Pre-nasal snout } \\
\text { length (PNS) }\end{array}$ & 5.5 & 11.8 & 29 & $\begin{array}{l}\text { Anterior margin of } \\
\text { pelvic fin (AMP) }\end{array}$ & 6.0 & 12.88 \\
\hline 8 & $\begin{array}{l}\text { Snout to greatest disc } \\
\text { width (SDW) }\end{array}$ & 15.2 & 32.62 & 30 & $\begin{array}{l}\text { Posterior margin of } \\
\text { pelvic fin (PMP) }\end{array}$ & 11.1 & 23.82 \\
\hline 9 & $\begin{array}{l}\text { Interorbital distance } \\
\text { (IOD) }\end{array}$ & 4.2 & 9.01 & 31 & Tail width (TW) & 8.4 & 18.03 \\
\hline 10 & Eye length (EL) & 0.6 & 1.29 & 32 & $\begin{array}{l}\text { Height of } 1^{\text {st }} \text { dorsal fin } \\
\text { (HFD) }\end{array}$ & 4.8 & 10.3 \\
\hline 11 & $\begin{array}{l}\text { Interspiracular } \\
\text { distance (ISD) }\end{array}$ & 3.0 & 6.44 & 33 & $\begin{array}{l}\text { Length of } 1^{\text {st }} \text { dorsal } \\
\text { fin (LFD) }\end{array}$ & 2.9 & 6.22 \\
\hline 12 & Spiracle length (SPL) & 1.45 & 3.11 & 34 & $\begin{array}{l}\text { Length of } 2^{\text {nd }} \text { dorsal } \\
\text { fin(LSD) }\end{array}$ & 3.5 & 7.51 \\
\hline 13 & Spiracle width (SPW) & 0.95 & 2.04 & 35 & $\begin{array}{l}\text { Height of } 2^{\text {nd }} \text { dorsal } \\
\text { fin(HSD) }\end{array}$ & 6.0 & 12.88 \\
\hline 14 & Mouth width (MW) & 2.4 & 5.15 & 36 & $\begin{array}{l}\text { Length of dorsal lobe } \\
\text { of caudal fin (LDC) }\end{array}$ & 7.0 & 15.02 \\
\hline 15 & $\begin{array}{l}\text { Upper tooth band } \\
\text { width (UTB) }\end{array}$ & 1.0 & 2.15 & 37 & $\begin{array}{l}\text { Length of ventral lobe } \\
\text { of caudal fin (LVC) }\end{array}$ & 6.9 & 14.81 \\
\hline 16 & $\begin{array}{l}\text { Lower tooth band } \\
\text { width (LTB) }\end{array}$ & 1.0 & 2.15 & 38 & $\begin{array}{l}\text { Height of dorsal lobe } \\
\text { of caudal fin (HDC) }\end{array}$ & 3.0 & 6.44 \\
\hline 17 & $1^{\text {st }}$ gill width & 1.0 & 2.15 & 39 & $\begin{array}{l}\text { Height of ventral lobe } \\
\text { of caudal fin (HVC) }\end{array}$ & 2.5 & 5.36 \\
\hline 18 & $2^{\text {nd }}$ gill width & 1.2 & 2.58 & 40 & $\begin{array}{l}\text { Distance between } \\
\text { dorsal fins (DBD) }\end{array}$ & 2.4 & 5.15 \\
\hline 19 & $3^{\text {rd }}$ gill width & 1.0 & 2.15 & 41 & $\begin{array}{l}\text { Distance between } 2^{\text {nd }} \\
\text { dorsal and caudal fin } \\
\text { (SDC) }\end{array}$ & 3.5 & 7.51 \\
\hline 20 & $4^{\text {th }}$ gill width & 1.1 & 2.36 & 42 & $\begin{array}{l}\text { Snout to cloaca length } \\
\text { (SCL) }\end{array}$ & 24 & 51.5 \\
\hline 21 & $5^{\text {th }}$ gill width & 0.9 & 1.93 & 43 & $\begin{array}{l}\text { Cloaca to caudal fin } \\
\text { length (CLC) }\end{array}$ & 22.6 & 48.5 \\
\hline 22 & $\begin{array}{l}\text { Snout to } 1^{\text {st }} \text { dorsal fin } \\
\text { length (SFD) }\end{array}$ & 28.5 & 61.16 & 44 & $\begin{array}{l}\text { Electric organ length } \\
\text { (EOL) }\end{array}$ & 11.2 & 24.03 \\
\hline 23 & $\begin{array}{l}\text { Snout to 2nd dorsal } \\
\text { fin length (SSD) }\end{array}$ & 33.5 & 71.89 & 45 & $\begin{array}{l}\text { Electric organ width } \\
\text { (EOW) }\end{array}$ & 4.6 & 9.87 \\
\hline
\end{tabular}

by-catch by gill net fishing. The rare landing may also have resulted from discarding the species as the demand and value is not very high amongst the 
fishers and consumers. It can also be assumed that it might have gone a population depletion due extensive bottom trawling and targeted demersal ray fishing practices. This report also indicates the Prestonian and Wallacean knowledge shortfall regarding elasmobranch species here in Bangladesh region of the Bay of Bengal.

Considering the characteristics of the collected specimen in Cox's Bazar, we confirm the presence of $N$. prodorsalis in Bangladeshi waters and increasing and confirming its distribution another $\sim 700 \mathrm{~km}$ in the Bay of Bengal from Andaman sea.

\section{CONCLUSION}

The results of this report are crucial, as they enhance our knowledge of the distribution of Narcine prodorsalis in the Bay of Bengal and also increasing the richness of elasmobranch diversity in Bangladesh. More systematic researches are cardinal in this area on abundance, ecology and biology of electric rays in order to assess their conservation status and threats in the extremely data poor Bay of Bengal.

Acknowledgements: The authors would like to thank Department of Zoology for hosting the research on elasmobranchs in Bangladesh and all the respondents who participated in the survey. The authors are also grateful to WCS, Bangladesh for their support in this project and to Hasan Arif Rahman for helping with mapping.

\section{LITERATURE CITED}

AKHILESH, K. V., BINEESH, K. K., GOPALAKRISHNAN, A., JENA, J. K., BASHEER, V. S. and PILLAI, N. G. K. 2014. Checklist of Chondrichthyans in Indian waters. Journal of the Marine Biological Association of India 56(1): 109-120.

BIGELOW, H. B. and W. C. SCHROEDER. 1953. Fishes of the western North Atlantic. 2. Sawfishes, skates, rays and chimaeroids. Mem. Sears Fdn mar. Res. 2(15): 588 pp.

CARVAlHO, M. D., COMPAGNO, L. J. V. and LAT, P. R. 1999a. Torpediniformes: Narcinidae, Numbfishes. FAO species identification guide for fishery purposes. The living marine resources of the Western Central Pacific. Batoid fishes, chimaeras and bony fishes part 1 (Elopidae to Linophrynidae), 3.

DE CARVALHO, M. R. 1999b. A systematic revision of the electric ray genus Narcine Henle, 1834 (Chondrichthyes: Torpediniformes: Narcinidae), and the higher-level phylogenetic relationships among the orders of elasmobranch fishes (Chondrichthyes). Ph.D. thesis, City University of New York. pp. 735.

DE CARVAlHO, M. R., SÉRET, B. and COMPAGNO, L. J. V. 2002. A new species ray of the genus Narcine Henle, 1834 from the South-Western Indian Ocean (Chondrichthyes: Torpediniformes: Narcinidae). African Journal of Marine Science 24: 135-149. 
DE CARVAlHO, M. R. and RANDALL, J. E. 2003. Numbfishes from the Arabian Sea and surrounding gulfs, with the description of a new species from Oman (Chondrichthyes: Torpediniformes: Narcinidae). Ichthyological Research 50(1): 0059-0066.

ESTUPIÑAN-MONTAÑO, C. and GALVÁN-MAGAÑA, F. 2015. First records of the leopard electric ray Narcine leoparda (Torpediniformes: Narcinidae) in the Ecuadorian Pacific. Revista de Biologia Marinay Oceanografía 50(3): 593-596.

HOQ, M.E., HAROON, A.Y. and HUSSAIN, M.G. (Eds.). 2011. Shark fisheries in the Bay oF Bengal, Bangladesh: Status and potentialities. Support to Sustainable Management of the BOBLME Project, Bangladesh Fisheries Research Institute.

HOWARD, R., AHMAD, A. and SHEIN, U.S.H. 2015. Shark and Ray Fisheries of Myanmar-status and socio-economic importance (No. 12). Report.

LAST, P., NAYLOR, G., SÉRET, B., WHITE, W., DE CARVAlHO, M. and STEHMANN, M. (Eds.). 2016. Rays of the World. Csiro Publishing. Australia.

MONKOLPRASIT, S. 1941. The electric rays found in Thailand. Bull. US Nat. Mus 100: 13.

RAHMAN, A. K. A., KABIR, S. M. H., AHMAD, M., AHMED, A. T. A., AHMED, Z. U., BEGUM, Z.N.T., HASSAN, M.A. and KHONDKER, M. 2009. Encyclopedia of Flora and Fauna of Bangladesh. Asiatic Society of Bangladesh, Dhaka. Marine Fishes. 24.

WANG, Y., VIDTHAYANON, C. and SAMIENGO, B. 2009. Narcine prodorsalis. The IUCN Red List of Threatened Species 2009:e.T161545A5448211.http://dx.doi.org/10.2305/IUCN.UK.20092. RLTS.T161545A5448211.en.

(Manuscript received on 7 November, 2018; revised on 17 November, 2018) 